\title{
MKOMAZI GAME RESERVE
}

\section{By David Anstey}

During the past decade the slow retreat of wild life from its former wide range in northern Tanganyika has quickened. In many areas its disappearance is an accomplished fact; in others, such as the north Tanga country, the game population has been reduced to a figure that is probably below the minimum density for continued existence.

In these unhappy circumstances, the Game Department asked for a new reserve in a stretch of country as yet uninhabited and, in October, 1951, the Mkomazi Game Reserve was gazetted.

The reserve lies along the Kenya-Tanganyika boundary from about $\mathbf{3 0}$ miles inland from the coastal village of Vanga to a few miles south of Lake Jipe. The western boundary follows the foothills of the Pare Mountains and the Umba River. The area is approximately 1,100 square miles, and lies between 600 and 2,600 fect above sea-level, with mountain ranges rising up to 5,500 feet in the centre and north.

The flora over the plains is that well-known East African Acacia-Commiphora thorn tree community with grass plains, which was so completely described and studied by B. D. Burt in the 1030's.

Scenically the northern part of the reserve is the most attractive. From one valley, green or golden brown according to season, Kilimanjaro's white cap may be seen, quite filling the valley's northern end. The Mbugas (areas of open grassland) which are liable to flooding in the wet season, are surrounded by Acacia spirocarpa, A. usambarensis and Commiphora spp. with odd Adonsonia digitata (the giant Baobab) on the fan slopes of the neighbouring hills. This vegetation thickens in places until it merges into the "dry ravine thicket" of Acacia spp., Grewia bicolor, Capparis spp., Acalypha fruticosa (a rhinoceros dainty), Euphorbia spp. and Sansevieria spp. Towards the Pare hills the thicket communities become dominant in places, while further south on the light rainfall red laterite eluvial soil, Commiphora is almost the only tree that can exist. The hills of over 4,000 feet are capped with rainforest remnants; but they are only of importance as specialized game habitats in the central Pare and Maji Kununuwa ranges in the north.

The northern grasslands are populated with eland, oryx, zebra, impala, Grant's gazelle, gerenuk, Coke's hartebeest the commonest animal, and giraffe. The carnivora are represented by 
lion, cheetah and leopard. The animals are still very shy and there are too many wild dogs.

These grasslands are the home of many rhinoceros and at least three good sized herds of buffalo. The rhino have shown how much they like the open spaces now that it is safe to be there and the buffalo have been seen more frequently in the open valleys instead of only on the denser hillside. The elephant fluctuate in numbers but, except during the long rains, there are rarely less than 1,000 in the reserve.

In the centre of the rescrve there is a mountain range loosely described as "The Tussas", whose main valley is another centre of game. Until very recently the large number of caves found here were used by African hunters, who sold the game meat in the nearest villages. Water is very searce, and the few watering places well hidden from the casual seeker. Those used by patrolling game scouts include a hollow baobab tree which holds up to sixty gallons of water and never dries up, crevices in rocky hills into which the water drains from above and must be baled out with a long ladle, natural rock tanks high up the side of cliffs, and small springs that may have just been visited by clephants and churned into a muddy soup.

'The woodland game so far recorded includes:-Greater and lesser kudu, waterbuck, steinbuck, duiker and on the hills, klipspringer. Further eastwards the river bank of the Umba provides tall trees in which are Colobus and Sykes' monkeys.

The first Europeans to cross this country were Baron von der Decken and his companion Thornton in July, 1861. The account of their journey to Kilimanjaro, written in German, is full of detailed daily observations. They travelled from Mombasa across the semi-desert on the Kenya side and then from the huge mountain mass of Kasigau, stecred for the South Pare mountains. The Baron's guides obviously did not know the country, and the whole caravan very nearly perished of thirst in the Tussa hills, a precedent nearly followed by myself when re-exploring this country in 1952; but I was more fortunate than von der Decken, for baboons disclosed to me their water supply in a rocky hillside crevice. Thornton made a very interesting and quite accurate map of their journey, and on his way back discovered the falls that bear his name at Gonja in the South Pares.

Count 'Ielcki on the journey in which he discovered Lakes Rudolph and Stcphani passed through Same, and along the Kaili valley behind the central Pares. The large waterhole where he camped and saw so much game just before Lake Jipe is still the same fine game area as when he passed about 1886, except 
that there is now a game scout's house some miles off, to warn away the local people who are no longer too frightened of the Masai to leave their mountain homes. Another interesting descriptive book is one called Au Kilimanjaro by Monseigneur Le Roi, a Roman Catholic missionary who passed through this country when on his way to start the first Roman Catholic mission in Chaggaland. He gives a graphic description of a meeting with a lion just by what is now the northern boundary of the reserve.

The war of 1914-1918 brought humanity for a time to this quite empty country. The Germans established an outpost beyond the Tussa hills from which they laid bombs on the Mombasa-Nairobi railway, and even laid a telephone line to the border. Von Lettow-Vorbeck, the German commander, describes in his book how he bicycled along an elephant road when visiting the outpost, and the old men of Pare describe with feeling how they had to carry supplies to the askari.

It seems probable that in carlier times this area was permanently inhabited, and not a country known to foot travellers only. With the motor car, a rapid decrease in foot caravans has left the reserve country unknown for the last twenty years, except to Arab and African poachers.

Since 1952, whenever funds and time have allowed, the reserve has been explored and mapped until at last most of it is known. Game scouts' stations from which it is hoped to control the poaching of game meat and ivory have been sited and constructed by the scouts themselves.

The need for dry season water is very great, for over hundreds of square miles there is none. Although many animals seem not to be worried by this water shortage, small experimental dams are being constructed and a larger site has been chosen where a dam will be built when funds are available. A rough bush camp for visitors is also under construction and will be completed shortly.

Much of the value of this sanctuary lies in its being uninhabited except at one corner, for game and men cannot live together when the game is as large as elephant. There is also no other reserve in Tanganyika with the same scries of vegetational and faunal communities, except where an increasing human population has to be reckoned with. 